\title{
Radiation balance in a soybean ecosystem in the Amazon ${ }^{1}$
}

\author{
Balanço de radiação em ecossistema de soja na Amazônia
}

\author{
Paulo Jorge de Oliveira Ponte de Souza ${ }^{2 *}$, Edson José Paulino da Rocha ${ }^{3}$, Aristides Ribeiro ${ }^{4}$ Everaldo \\ Barreiros de Souza ${ }^{3}$
}

\begin{abstract}
The continuous advance of the agricultural border in the Amazon has been worrying the scientific community due to the possible environmental impacts caused by this change in land use. The present work evaluated the behavior of the radiation balance components over the soybean crop (Glycine Max (L.) Merryl) in an Amazon area of continuous advance of the agricultural border. The radiation components were continuously monitored during the soybean cycle in 2006 and 2007 in an area of 200 ha. The soybean cultivation in the Amazon presented an abrupt change in the radiation balance components, with the consequent reduction in the energy available to the environment due to the increase in the surface reflection. There was a significant contribution of the diffuse radiation component in the soybean interception during cloudy conditions, even under incomplete canopy covering. Moreover, after the canopy closure, a similar interaction between soybean and solar radiation occurs, regardless of the cloud condition.
\end{abstract}

Key words - Amazonia. Soybean. Surface-atmosphere interactions.

Resumo - O avanço da fronteira agrícola na Amazônia, da forma como vem sendo realizado, tem deixado a comunidade cada vez mais preocupada ante os possíveis impactos ambientais decorrentes desta mudança no uso da terra, devido à grande importância que a Amazônia representa para o clima global. Neste trabalho avaliaram-se os componentes do balanço de radiação à superfície, ao longo do ciclo da soja (Glycine Max (L.) Merryl), em uma área de avanço da fronteira agrícola na Amazônia. Os componentes do balanço de radiação foram monitorados continuamente durante o ciclo da soja, em 2006 e 2007, em uma área de 200 ha de extensão. O monocultivo da soja na Amazônia apresentou uma contínua mudança nos componentes do balanço de radiação, tendo como consequência uma redução na energia disponível para o ambiente devido o aumento na reflexão da superfície. Observou-se uma importante contribuição da radiação solar difusa na interceptação da soja durante dias nublados, mesmo sob condições de dossel incompleto. Por outro lado, após o fechamento do dossel, a interação da soja com a radiação acontece de forma semelhante, independente da condição de nebulosidade.

Palavras-chave - Soja. Amazônia. Interação planta-atmosfera.

\footnotetext{
* Corresponding author

${ }^{1}$ Received 05/01/2010; accepted em 25/10/2010

Projeto de pesquisa financiado pelo CT-Hidro/CNPq; parte da Tese do primeiro autor apresentada ao Departamento de Engenharia Agrícola, DEA/

UFV, Minas Gerais

${ }^{2}$ Instituto Sócio Ambiental e dos Recursos Hídricos, ISARH/UFRA, Belém-PA, Brasil, paulo.jorge@ufra.edu.br

${ }^{3}$ Faculdade de Meteorologia, FAMET/UFPa, Belém-PA, Brasil, eprocha@ufpa.br, everaldo@ufpa.br

${ }^{4}$ Departamento de Engenharia Agrícola, DEA/UFV, Viçosa-MG, Brasil, ribeiro@ufv.br
} 


\section{Introduction}

For several years, the Amazon was the scene for various studies on land use on socioeconomic (SOARESFILHO et al., 2005), hydrological (COHEN et al., 2007) and climate impacts (COSTA; YANAGI, 2006). Some results demonstrated that the rainforest replacement by pasture causes serious impacts, such as increase in air temperature (COSTA; YANAGI, 2006), increase in surface albedo (RANDOW et al., 2004) and reduced evapotranspiration (COHEN et al., 2007). However, most of these works consider that the land use change was only for pasture planting.

Due to the expansion of the agricultural frontier in this region, another approach has become more popular and has worried the community because of the environmental changes resulting from the advance of soybean monoculture in this region (DANTAS; FONTELES, 2005). The rapid expansion of soybean cultivation in Brazil was a result of the Brazilian government support and the favorable soil and weather conditions (FEARNSIDE, 2001). In the Amazon region, this activity has increased slowly and it began to rise due to the favorable conditions for the expansion of the soybean cultivation, taking advantage of transition areas of savanna-forest or of available cleared or degraded land (DANTAS; FONTELES, 2005).

Deforestation with pasture production purposes causes a change from $12.9 \%$ to $18.4 \%$ in the surface albedo, respectively (RANDOW et al., 2004). The same authors found albedo values of 13 and $20 \%$, for forest and pasture, respectively, for the southwest of the Amazon.

However, the replacement of forest cover by soybean and the reuse of pasture areas for the soybean planting causes more significant changes due to the crop physiology and the change in architecture that soybean presents over the cycle (SOUZA et al., 2008). The interception of radiation by the crop changes the partition of the canopy evapotranspiration, affecting the local microclimate created by the crop (SAUER et al., 2007).

Results of Costa et al. (2007) show that the replacement of the Amazon rain forest by soybean cultivation causes greater reduction in rainfall in this region when compared to land use for farming, due to the high albedo of soybean. Souza et al. (2008) observed a mean relative increase in albedo of $93 \%$ for the whole soybean cycle, due to this new model of land use change, which can greatly contribute to the reduction in net radiation.

Furthermore, the efficiency with which the solar radiation is intercepted by the culture and how this energy interacts with the vegetation are determinants for agricultural productivity (CAVIGLIA et al., 2004). Results obtained by Souza et al. (2009) show that the soybean crop in the Amazon has high radiation use efficiency due to the enormous amount of diffuse radiation in the region.

Therefore, it is very important to evaluate and study the irradiative behavior in this new type of Amazon ecosystem, since such information will enable a better understanding of how local/regional climate may be affected by the advance of soybean plantations in the Amazon and how these interactions can influence the soybean productivity. The objective of this study is to quantify the components of the radiation balance in an area of advance of agricultural frontier in the Amazon.

\section{Materials and methods}

\section{Experimental site}

The experiment was conducted in Paragominas city, Pará State, Brazil. The choice of this city for the study was due to the fact that this region has suffered a great expansion of soybean cultivation in recent years. The experiment was carried out during 2006 and 2007, in a soybean crop area with a continuous extension of 200 ha $\left(02^{\circ} 59^{\prime} 08^{\prime \prime} \mathrm{S}\right.$ and $47^{\circ} 19^{\prime} 57^{\prime}$ 'W). Although the most recommended cultivar for this region is Tracajá (intermediate), which was used in the 2007 experiment, in 2006 it was used the cultivar Candeia, since it is a new variety developed by EMBRAPA, with good acceptance by producers.

In the 2006 experiment the soil was mechanically prepared with no-till at 0.45 row spacing with 222,000 plants $\mathrm{ha}^{-1}$ as population. In 2007, the soil was prepared with conventional tillage at 0.50 row spacing, with 200,000 plants ha ${ }^{-1}$. Before sowing, the seeds were prepared with inoculation (Bradyrhizobium japonicum), fungicides and insecticides. The Sowings occurred in February $5^{\text {th }} 2006$ and February $23^{\text {rd }} 2007$, at a rate of $26-28$ seeds $\mathrm{m}^{-2}$. The final harvest was in June $15^{\text {th }} 2006$ and June $21^{\text {st }} 2007$.

A 3-meter-high instrumented micrometeorological tower was installed in the center of the experimental area. Meteorological sensors were connected to a CR10X datalogger (Campbell Scientific, Inc., Logan, Utah) and to an AM416 multiplex (Campbell Scientific, Inc., Logan, Utah). Data measurements were carried out every ten seconds during 2007 and 2008, providing total and average values every ten minutes. The data acquisition period used in this work ranges from February to June in 2006 and (the same period) in 2007 .

\section{Radiation balance measurements}

The incident short wave radiation $\left(Q_{g}\right)$ was monitored using a pyranometer CMP3 (Kipp \& Zonen, 
Campbell Scientific), and the reflected component of the solar radiation $\left(Q_{r}\right)$ was measured using an inverted pyranometer. The sensor was installed at the height of 2.5 meters.

The short wave radiation transmitted to the ground $\left(Q_{\text {trans }}\right)$ was measured continuously by a line pyranometer (TSL, Delta-T Devices Ltd.) which was installed at the soil surface diagonally across the rows, as suggested by Albrizio and Steduto (2005). Thus, the radiation intercepted by the crop cover becomes more representative of the daily range than if performed punctually near the solar noon, although this method is also acceptable (EARL, DAVIS, 2005). The sensor was moved weekly around the tower to ensure randomness and avoid bias in the intercepted radiation data.

The net radiation $\left(\mathrm{R}_{\text {net }}\right)$ was continuously monitored by a net radiometer (NR-Lite, Campbell Scientific). The long wave net radiation $\left(\mathrm{L}_{\text {net }}\right)$ was obtained as a residue form the surface radiation balance equation:

$$
L_{n e t}=R_{n e t}-(Q g-Q r)
$$

Both the transmissivitity $(\tau)$ and reflectivity - albedo $(\alpha)$ coefficients were obtained by the ratios of transmitted $\left(\mathrm{Q}_{\text {trans }}\right)$ and reflected $\left(\mathrm{Q}_{\mathrm{r}}\right)$ short wave radiation with the incident short wave radiation $\left(\mathrm{Q}_{\mathrm{g}}\right)$, respectively:

$$
\begin{gathered}
\tau=\left(Q_{\text {trans }} / Q_{g}\right) \\
\alpha=\left(Q_{r} / Q_{g}\right)
\end{gathered}
$$

\section{Soybean development and growth analysis}

The phenological development was observed daily, according to Fehr and Caviness (1977) in a completely randomized experiment. Leaf area index was used in the analyses and it was estimated through the disc method (BENINCASA, 2003).

\section{Results and discussions}

\section{a) Meteorological conditions during the soybean experiment}

Table 1 shows the water availability and mean air temperature during each soybean crop stages in both experiments. It was verified a reduction in total rainfall in 2007, which was responsible for the leaf area reduction observed, when compared to 2006 (SOUZA et al., 2008). This reduction in total rain might have been caused by a positive anomaly in the surface temperature of the Pacific Ocean observed between October 2006 and April 2007, indicating the occurrence of El Niño (CPTEC, 2007).

Despite the occurrence of the rainy conditions during 2006 cycle, the mean air temperature was always above the one observed in 2007. Results from Dias et al. (2009), showed that the environmental condition in which the culture is exposed was a major factor in both the adaptation and the potentiality of soybean cultivation in the State of Ceará.

The probable cause for the discrepancy in temperature between both soybean cycles may be associated with the occurrence of lower minimum temperatures in 2007 in response to lower cloudiness and higher long wave lost observed in this year, which may have contributed to a lower daily average. Another important reason and perhaps the most likely, is that the 2007 experiment was conducted 12 kilometers away from the 2006 site, where there is a river with riparian forest about $2 \mathrm{~km}$ from the site, in the quadrant of the predominant wind, causing a reduction of about $1.5^{\circ} \mathrm{C}$ on the observed temperature in 2007.

Table 1 - Meteorological conditions over the soybean cycle

\begin{tabular}{ccccrcrccc}
\hline \multirow{2}{*}{ Phases } & \multicolumn{2}{c}{ Duration (days) } & \multicolumn{2}{c}{ Rainfall $(\mathrm{mm})$} & \multicolumn{2}{c}{ Tar $\left({ }^{\circ} \mathrm{C}\right)$} & \multicolumn{2}{c}{ T. min. $\left({ }^{\circ} \mathrm{C}\right)$} \\
\cline { 2 - 9 } & 2006 & 2007 & 2006 & 2007 & 2006 & 2007 & 2006 & 2007 \\
\hline Vegetative & 47 & 44 & 336.0 & 184.2 & 27.2 & 25.2 & 24.1 & 22.1 \\
Flowering & 11 & 11 & 135.1 & 36.0 & 26.5 & 25.4 & 24.1 & 22.4 \\
Frutification & 11 & 17 & 175.0 & 105.2 & 26.9 & 25.2 & 23.7 & 22.1 \\
Grain filling & 45 & 33 & 336.8 & 61.6 & 26.8 & 25.7 & 23.5 & 21.8 \\
Maturation & 16 & 14 & 29.3 & 23.4 & 27.2 & 25.5 & 21.9 & 21.0 \\
Total/average & 130 & 119 & 1012.2 & 410.4 & 26.9 & 25.4 & 23.5 & 21.9 \\
\hline
\end{tabular}




\section{b) Short wave net radiation}

\section{Partly cloudy days}

\section{Incident global radiation}

Throughout the experiment, the sky was partly cloudy or completely overcast, with no observed clear sky conditions because of the cycle coincidence with the rainfall season of the region. In the 2006 experiment, under partly cloudy sky conditions, the global radiation showed peaks between 910 and $1050 \mathrm{~W} \mathrm{~m}^{-2}$ throughout the crop cycle (FIG. 1).

Although there is less rain and less cloud cover in 2007, during partly cloudy days, the global radiation showed a pattern similar to that observed in 2006, with peaks ranging from 920 to $1170 \mathrm{~W} \mathrm{~m}^{-2}$ throughout the cycle (FIG. 1). However, the reduction in the amount of rainfall influenced the leaf development, altering the transmission of radiation through the canopy.

\section{Intercepted global radiation}

It was noticed a considerable change in the radiation that reaches the ground with the crop development (FIG. 2). During 2006, about $97 \%$ of incident radiation reached the soil in the early vegetative stage (18 DAS and LAI $=0.50)$.
With increasing vegetation cover, the fraction of radiation that reached the ground decreased to $18.5 \%$ during flowering $(\mathrm{LAI}=5.59)$, remaining below $10 \%$ by the end of the grain filling stage, when the LAI had reached its maximum value and began a gradual reduction $($ LAI $=6.9)$. Sauer et al. (2007) observed a maximum global transmission of radiation to the ground of only $12 \%$ for the soybean grown in the United States, when the surface was completely covered (LAI > 4.9), during clear sky conditions.

Only during the maturation stage, it was observed an increase in the fraction of radiation that reaches the ground $(65.4 \%)$, although the value was lower than that of the early growing season, even with LAI close to zero. This feature is attributed to the difference in the radiation interception observed between the young and smaller plant with green leaves and the larger crop that begins to lose leaves until presenting only senescent material (SAUER et al., 2007).

In 2007 , approximately $74 \%$ of the radiation was transmitted to the soil during the growing season with LAI of 0.59 (stage V5), but during the flowering stage, when the IAF was 3.63, this fraction still represented $29 \%$ of the global radiation, indicating little radiation interception by

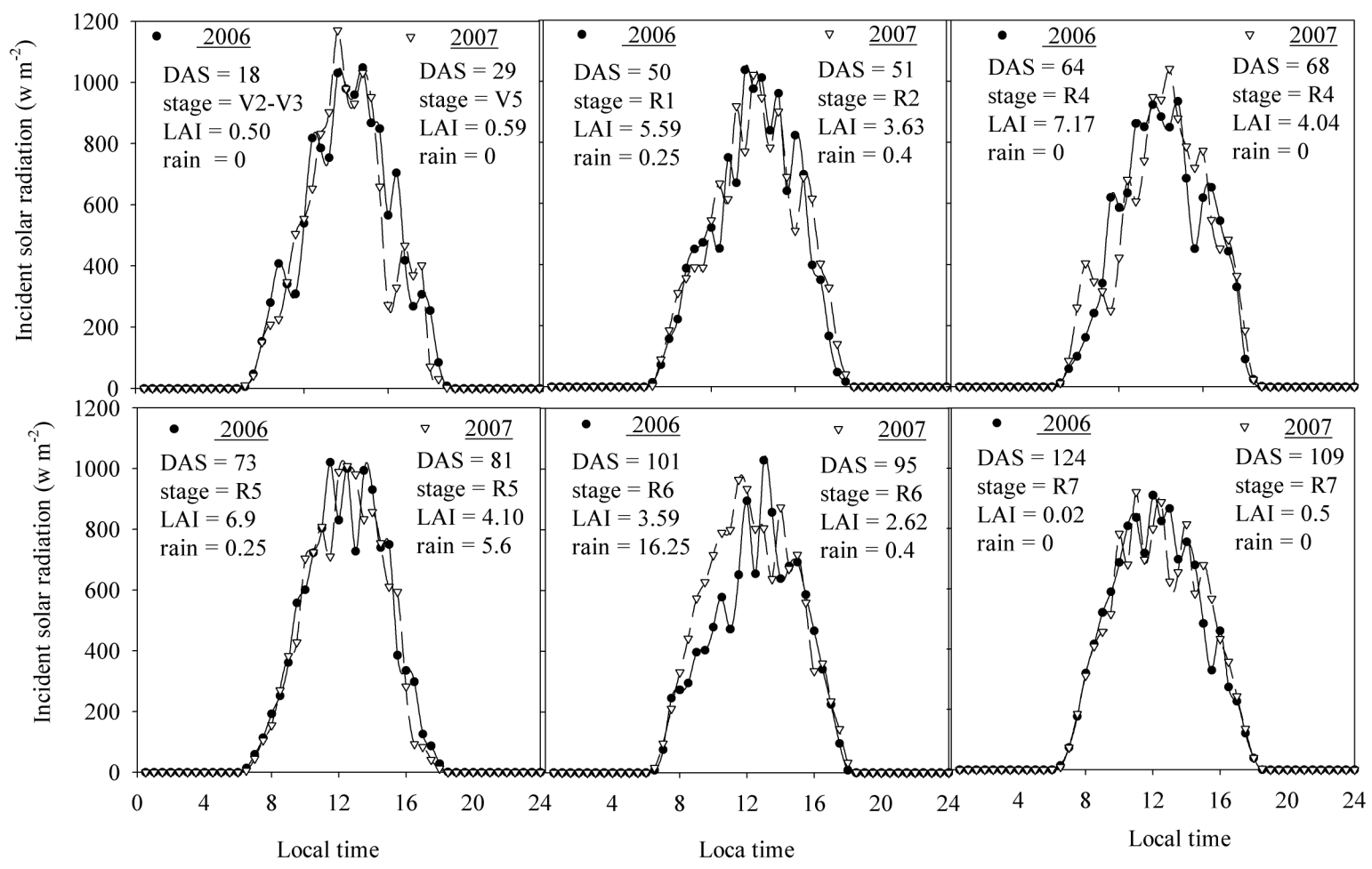

Figure 1 - Daily cycle of the incident global radiation over the soybean cycle under partly cloudy days (circles: 2006, triangles: 2007) 


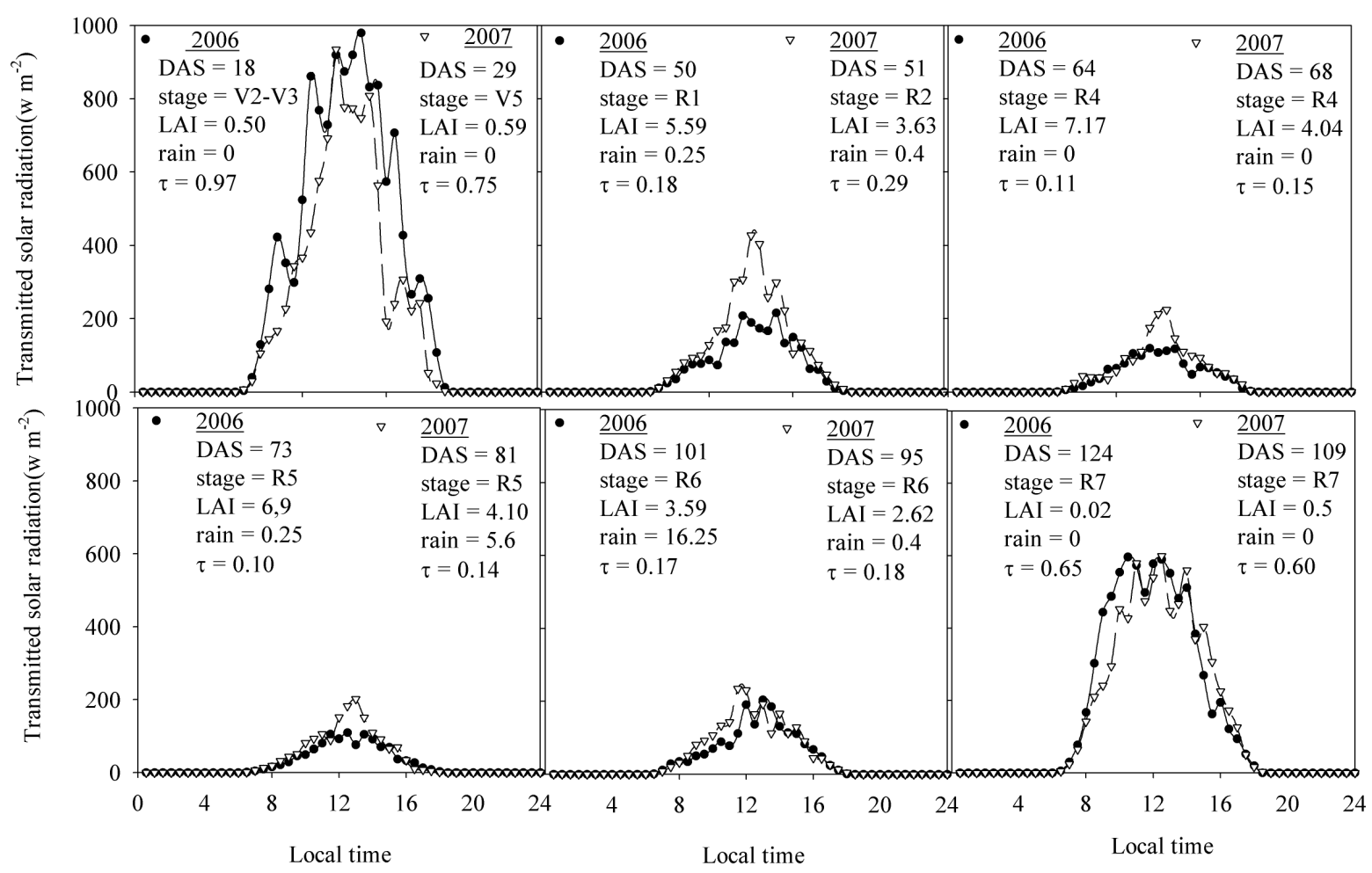

Figure 2 - Daily cycle of the transmitted global radiation over the soybean cycle under partly cloudy days (circles: 2006, triangles: 2007)

the crop in that year. From the fructification to the full pod stage, the soybean continued intercepting only between 82 and $86 \%$ of global radiation, different from the 2006 , when there was an interception up to $90 \%$ during the grain filling. Despite the difference caused by water restriction, during maturation, the behavior was similar in both years, with $60.6 \%$ of radiation reaching the ground.

\section{Reflected global radiation}

The reflected radiation by the culture showed a significant variation over the cycle, such as the radiation transmitted to the ground, depending directly on the land cover development (FIG. 3). The soybean albedo ranged from $16 \%$ during the vegetative phase to $22 \%$ when the canopy was completely closed under partly cloudy conditions.

The reflected radiation did not present much difference from the behavior found in 2006, even with the reduction in rainfall in 2007 . However, due to the reduction in the leaf area in this year, albedo remained higher during the full pod stage (R6), due to an early exposure of the soil, which contributed to the higher reflection (17.9\% in 2006 and $22.1 \%$ in 2007) because it was drier. According to Dalmolin et al. (2005), the higher the moisture content in the soil the smaller the surface reflection, once the soil becomes darker.

\section{Cloudy days}

\section{Incident global radiation}

In 2006, during cloudy days, the incident radiation showed greater variability throughout the day, ranging from 400 to $800 \mathrm{~W} \mathrm{~m}^{-2}$, which represented a reduction of $57 \%$ in the daily mean value observed in less cloudy days during the same year (FIG. 4).

As a result of the less rainy experiment in 2007, when compared to the 2006 experiment, it is noticed that the daily cycle of global radiation presented less variation, even on cloudy days. The maximum instantaneous values ranged between 600 and $800 \mathrm{~W} \mathrm{~m}^{-2}$, and because of major symmetry in the daily curve, the daily mean values were above those found in 2006 under the same cloud cover conditions (TAB. 2). 


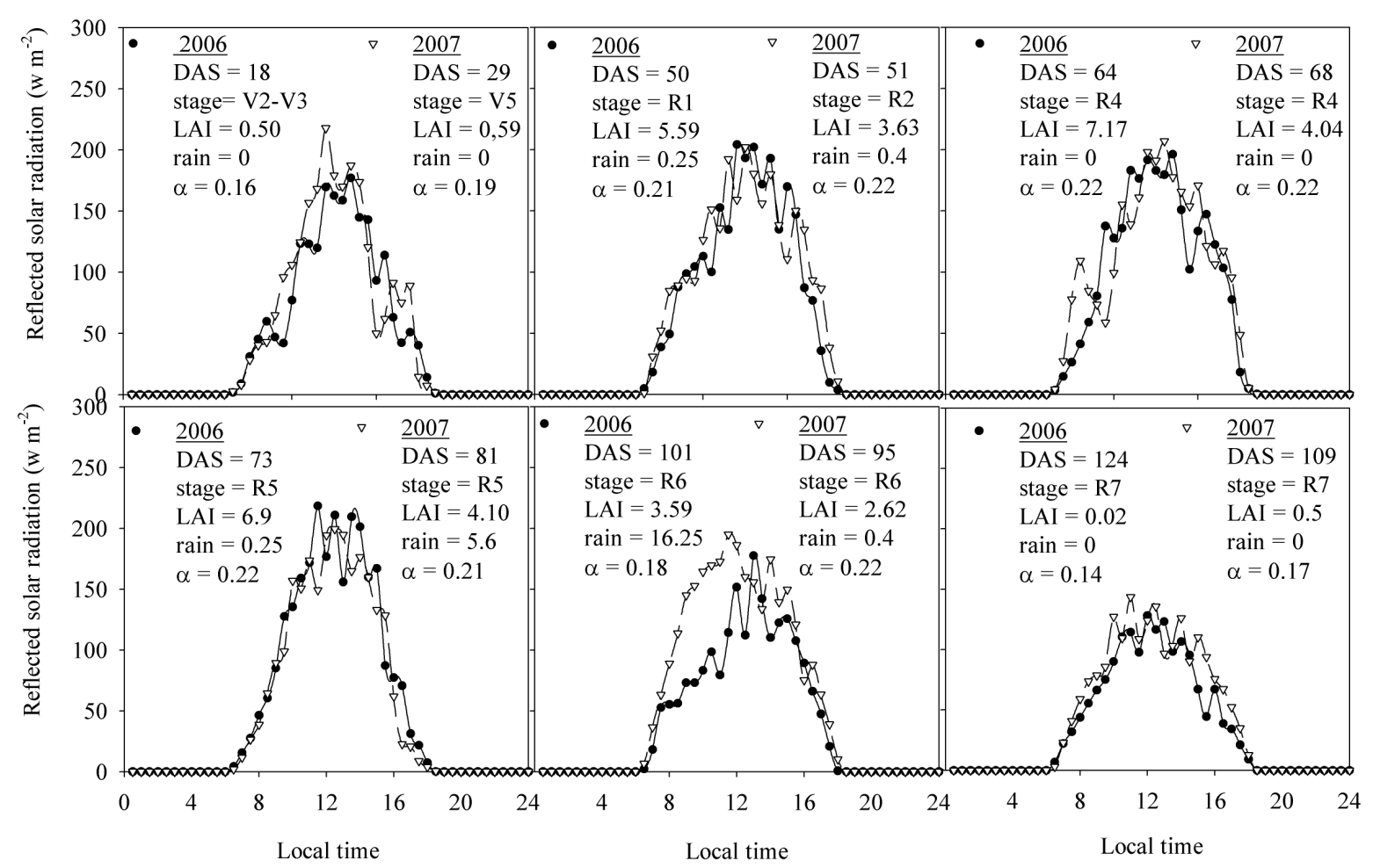

Figure 3 - Daily cycle of the reflected global radiation over the soybean cycle under partly cloudy days (circles: 2006, triangles: 2007)

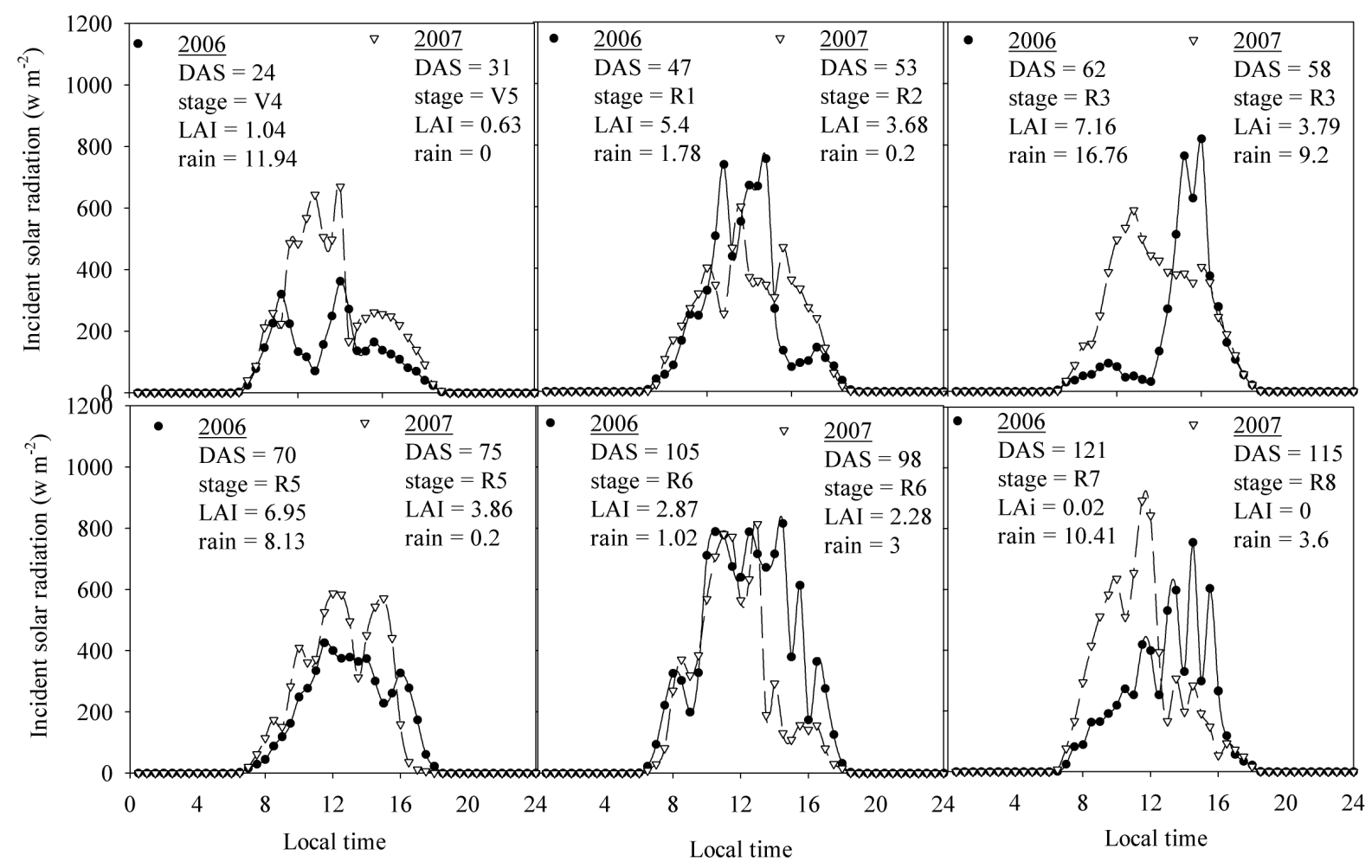

Figure 4 - Daily cycle of the incident global radiation over the soybean cycle under cloudy days (circles: 2006, triangles: 2007) 
Table 2 - radiation balance components over the soybean cycle. Standard error in parentheses

\begin{tabular}{ccccccccccc}
\hline \multirow{2}{*}{ Stages } & \multicolumn{2}{c}{$\mathrm{Q}_{\mathrm{g}}\left(\mathrm{MJ} \mathrm{m}^{-2} \mathrm{~d}^{-1}\right)$} & \multicolumn{2}{c}{$\mathrm{Q}_{\mathrm{r}}\left(\mathrm{MJ} \mathrm{m}^{-2} \mathrm{~d}^{-1}\right)$} & \multicolumn{2}{c}{$\mathrm{Q}_{\text {trans }}\left(\mathrm{MJ} \mathrm{m}^{-2}\right)$} & \multicolumn{2}{c}{$\mathrm{R}_{\text {net }}\left(\mathrm{MJ} \mathrm{m}^{-2} \mathrm{~d}^{-1}\right)$} & \multicolumn{3}{c}{$\mathrm{L}_{\text {net }}\left(\mathrm{MJ} \mathrm{m}^{-2} \mathrm{~d}^{-1}\right)$} \\
\cline { 2 - 11 } & 2006 & 2007 & 2006 & 2007 & 2006 & 2007 & 2006 & 2007 & 2006 & 2007 \\
\hline \multirow{2}{*}{ Vegetative } & 17.9 & 19.3 & 3.0 & 3.3 & 13.1 & 15.7 & 10.6 & 12.0 & -4.2 & -4.1 \\
& $( \pm 0.3)$ & $( \pm 0.4)$ & $( \pm 0.1)$ & $( \pm 0.1)$ & $( \pm 0.3)$ & $( \pm 0.3)$ & $( \pm 0.2)$ & $( \pm 0.3)$ & $( \pm 0)$ & $( \pm 0.1)$ \\
Flowering & 17.2 & 18.5 & 3.7 & 3.7 & 2.8 & 6.2 & 10.5 & 11.0 & -3.0 & -3.7 \\
& $( \pm 0.7)$ & $( \pm 0.7)$ & $( \pm 0.1)$ & $( \pm 0.1)$ & $( \pm 0.1)$ & $( \pm 0.3)$ & $( \pm 0.5)$ & $( \pm 0.4)$ & $( \pm 0)$ & $( \pm 0.1)$ \\
Fructification & 18.2 & 18.7 & 4.1 & 4.0 & 2.0 & 3.3 & 11.1 & 10.9 & -2.9 & -3.9 \\
& $( \pm 0.6)$ & $( \pm 0.6)$ & $( \pm 0.1)$ & $( \pm 0.1)$ & $( \pm 0.1)$ & $( \pm 0.1)$ & $( \pm 0.4)$ & $( \pm 0.4)$ & $( \pm 0.1)$ & $( \pm 0.1)$ \\
Grain filling & 16.2 & 20.1 & 3.4 & 4.4 & 1.6 & 2.7 & 9.8 & 11.5 & -3.0 & -4.2 \\
& $( \pm 0.3)$ & $( \pm 0.5)$ & $( \pm 0.1)$ & $( \pm 0.1)$ & $( \pm 0)$ & $( \pm 0.1)$ & $( \pm 0.2)$ & $( \pm 0.3)$ & $( \pm 0)$ & $( \pm 0.1)$ \\
Full Seed & 17.8 & 19.5 & 3.0 & 4.1 & 5.8 & 4.9 & 11.7 & 11.1 & -3.7 & -4.2 \\
& $( \pm 0.4)$ & $( \pm 0.6)$ & $( \pm 0.1)$ & $( \pm 0.1)$ & $( \pm 0.2)$ & $( \pm 0.2)$ & $( \pm 0.3)$ & $( \pm 0.4)$ & $( \pm 0)$ & $( \pm 0.1)$ \\
Maturation & 19.3 & 18.9 & 2.7 & 3.1 & 12.5 & 11.2 & 11.3 & 11.3 & -5.2 & -4.5 \\
& $( \pm 0.4)$ & $( \pm 0.6)$ & $( \pm 0.1)$ & $( \pm 0.1)$ & $( \pm 0.3)$ & $( \pm 0.4)$ & $( \pm 0.3)$ & $( \pm 0.4)$ & $( \pm 0.1)$ & $( \pm 0.1)$ \\
\hline
\end{tabular}

\section{Intercepted global radiation}

Although there was less incident radiation on the culture during cloudy days, less irradiance was transmitted to the ground during the vegetative stage in 2006 (72\%). During the same stage, under partly cloudy days, this fraction was $92 \%$ even with a very small difference in the LAI. This demonstrates the importance of the diffuse component of radiation on interception by crops (FIG. 5).

From flowering to grain filling stage, the fraction of radiation that reaches the soil has showed similar variation to partly cloudy days, with a slightly decrease from 19.9 to $9.27 \%$. During these stages, the LAI was always above

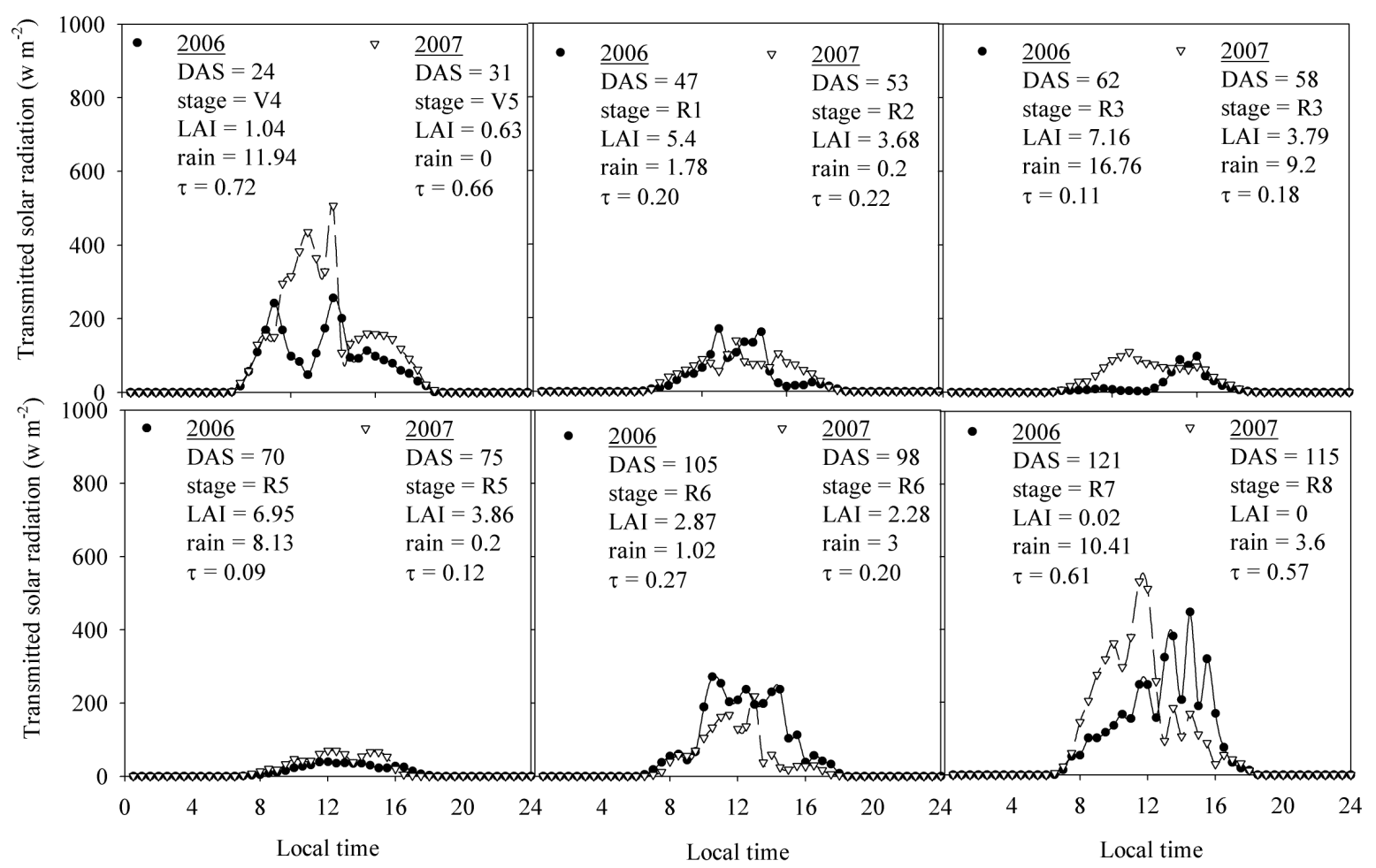

Figure 5 - Daily cycle of the transmitted global radiation over the soybean cycle under cloudy days (circles: 2006, triangles: 2007) 
5, which suggests that, under closed canopy conditions, the soybean shows the same behavior in intercepting the radiation, regardless of the degree of cloudiness. At maturation, the fraction of radiation that reaches the soil increased to $60.7 \%$, which was slightly lower than that observed during the same stage under partially cloudy days $(65 \%)$, as a consequence of the greater degree of diffuse radiation.

Despite the lower degree of cloudiness in 2007, which means less diffuse radiation, compared to the 2006 experiment, under cloudy days, there was a similar characteristic in the interaction of soybean with solar radiation between the years, under incomplete canopy cover conditions, in comparison to less cloudy conditions. During the vegetative stage, about $66 \%$ of the radiation had reached the ground, while this fraction was $74 \%$ under partly cloudy days, an important reduction also observed in 2006.

In 2007, however, especially during the periods when the canopy was expected to be complete (R1 to R5), the reduction in the leaf area caused by the decrease in water availability modified the interaction between the radiation and the crop. During these stages, it was observed a behavior similar to that of 2006, but slightly different from that under incomplete coverage.

In both years, during cloudy days, less radiation reached the ground due to the penetration of more diffuse radiation, but in 2007, soybean intercepted less radiation at higher LAI, under partly cloudy conditions, unlike 2006, when the crop presented similar characteristic in radiation interception, regardless of the degree of cloudiness.

\section{Reflected global radiation}

On cloudy days, the fraction of radiation reflected by the crop was higher during flowering and grain filling stage (LAI > 5), when compared to partly cloudy days. During the vegetative, full pod and maturation stages, when the crop coverage was incomplete, albedo was lower than under partially cloudy days (FIG. 6). Results from Fontana et al. (1991), obtained for soybeans in Rio Grande do Sul (LAI > 7), demonstrated an increase in the surface albedo from 24 to $27 \%$ under partly cloudy to cloudy conditions, respectively.

Again, it is noticed the importance of canopy closure on the interaction between the culture and the solar radiation, once during cloudy days, besides the intensity reduction in the incident radiation, it is also observed a shift in its quality, which contribute to a different reflection of some crop surfaces, according to the spectrum of the incident radiation (BLAD; BACKER, 1972). On cloudy days, the soybean presented albedo ranging from $14.4 \%$ during the vegetative stage to $23.9 \%$ during the grain filling, in both years.

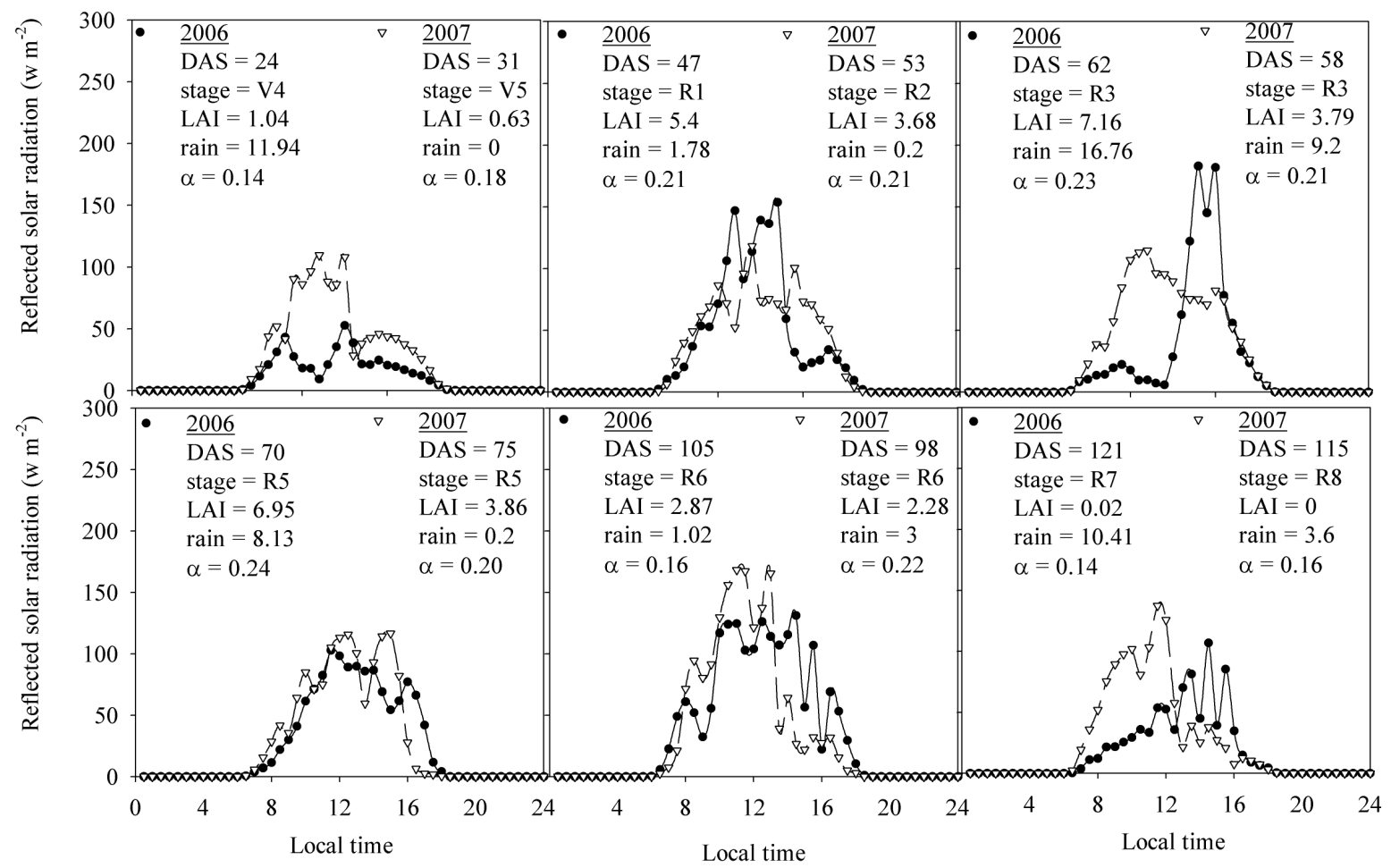

Figure 6 - Daily cycle of the reflected global radiation over the soybean cycle under cloudy days (circles: 2006, triangles: 2007) 


\section{c) Long wave net radiation}

\section{Partly cloudy days}

The canopy cover influenced directly the longwave net radiation (FIG. 7). In both years, the long-wave balance presented similar variation throughout the day during incomplete canopy closure. It was noticed the occurrence of instantaneous peak near $150 \mathrm{~W} \mathrm{~m}^{-2}$ around midday local time as a result of the surface temperature effect on the radiation emission.

At night, the long wave net radiation ranged around 25 and $30 \mathrm{~W} \mathrm{~m}^{-2}$, independent of the culture development. The predominance of negative values in the long wave balance suggests a loss from the surface always higher than the atmospheric radiation, depending, in this case, on the changes in the canopy cover such as those found by Fontana et al. (1991).

After canopy closure, there is a reduction in the long wave balance due to the decrease in the irradiative surface loss. As the leaf area increases and the soil become less exposed, there is an increase in energy consumed by evapotranspiration, which contributes to a reduction in surface temperature influencing directly the long wave emission (SOUZA et al., 2007).
Another fact is that, as the leaf area increases, there is an increase in the reflected radiation, which reduces the amount of available short-wave radiation (SOUZA et al., 2010). Results from Sauer et al. (2007) showed that even on a clear day with little atmospheric radiation, the longwave net radiation above the soybean canopy was always below $100 \mathrm{~W} \mathrm{~m}^{-2}$, under maximum canopy cover.

However, during the 2007 experiment, it was not observed the same effect of the canopy cover on the long wave net radiation. Despite its lower leaf area, during periods of full canopy closure, the crop behavior in 2007 was similar to that observed during periods of incomplete coverage, with instantaneous peaks of the same magnitude $\left(150 \mathrm{~W} \mathrm{~m}^{-2}\right)$. This behavior can be associated both to a leaf area reduction and to a water restriction that occurred in this year, which may have affected the soybean emission of long waves.

\section{Cloudy days}

During cloudy days, the long wave net radiation showed the same behavior observed under partly cloudy condition, although with lower magnitude (FIG. 8). This fact is due to the expected increase in atmospheric radiation that has contributed to a mean reduction of $17.7 \%$ and $31.8 \%$ on daily mean long wave balance over 2006 and 2007 cycle, respectively.

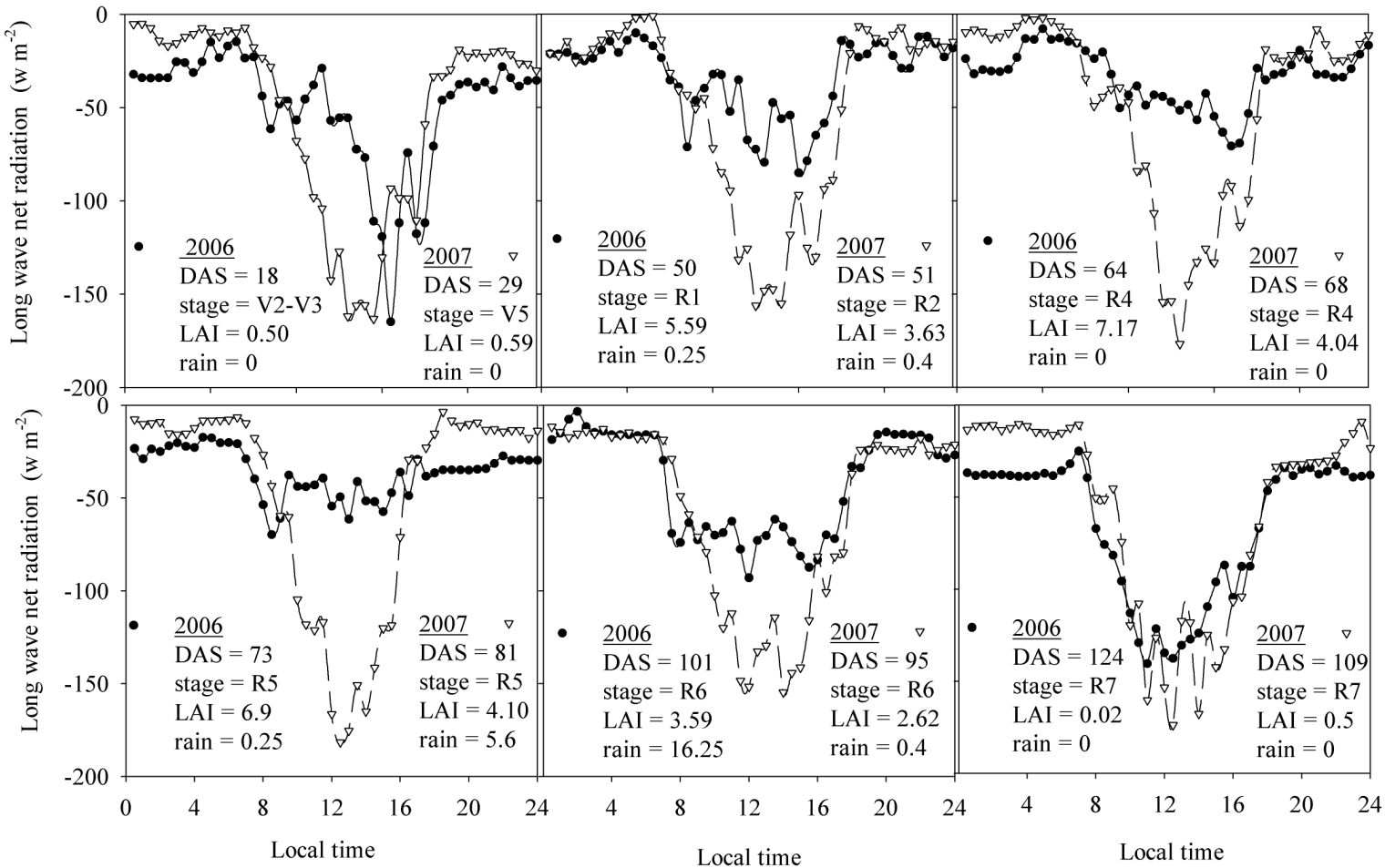

Figure 7 - Daily cycle of the long wave net radiation over the soybean cycle under partly cloudy days (circles: 2006, triangles: 2007) 


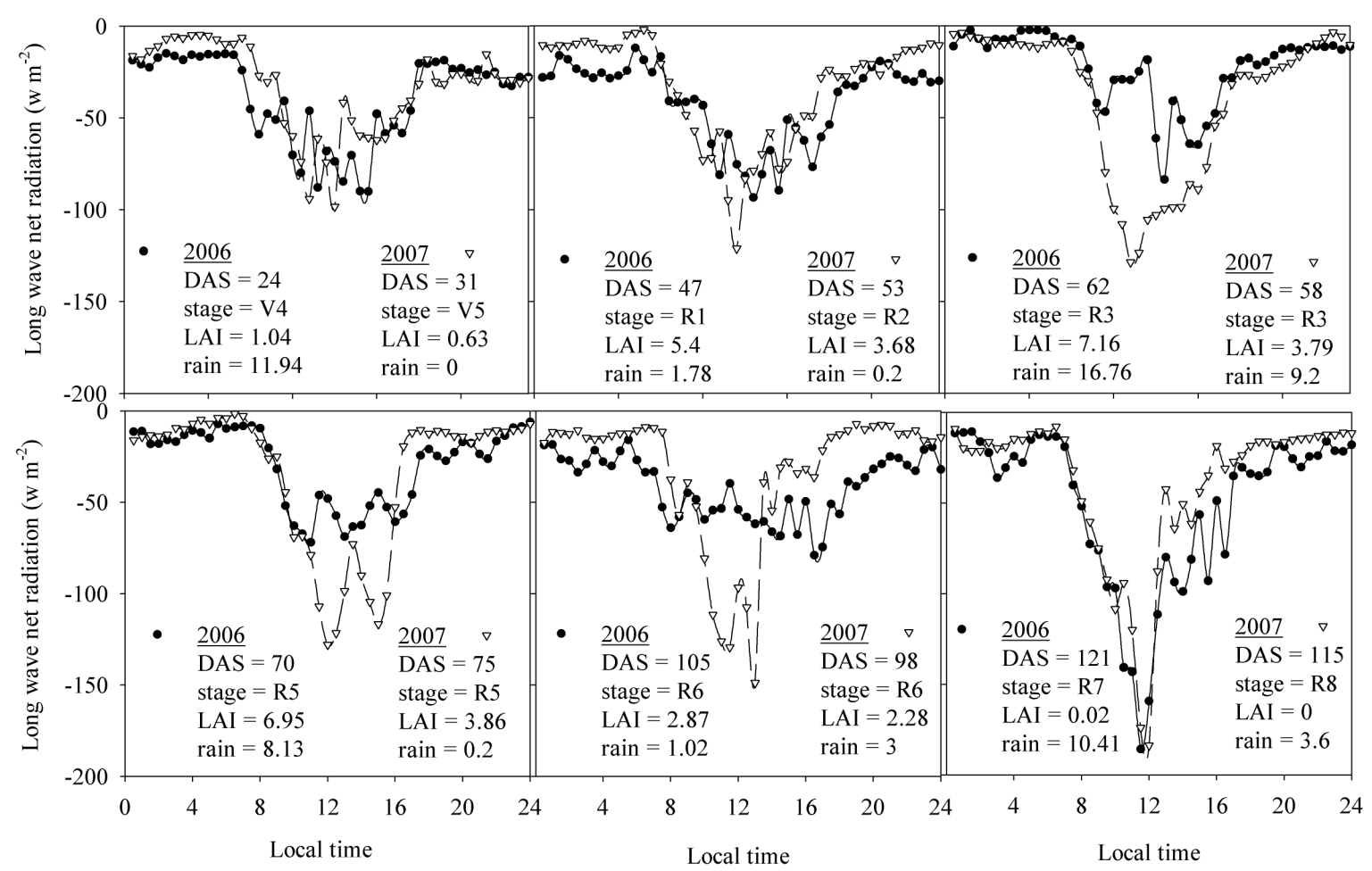

Figure 8 - Daily cycle of the long wave net radiation over the soybean cycle under cloudy days (circles: 2006, triangles: 2007)

During incomplete canopy closure, the daily cycle of the long wave net radiation was similar over both soybean cycles. Under full canopy closure, there was a slight reduction in the instantaneous values of the long-wave net radiation, especially under good water availability conditions (2006).

However, this small difference observed up to the maturation suggests that, on cloudy days, the effect of the atmospheric radiation plays an important role in controlling the long wave net radiation over the crop cycle, which attributes to the canopy development a secondary importance in this control.

Fontana et al. (1991) observed a reduction in longwave net radiation, from $-4.3 \mathrm{MJ} \mathrm{m}^{-2}$ day $^{-1}$ during partially cloudy days to $-1.8 \mathrm{MJ} \mathrm{m}^{-2}$ day $^{-1}$ during cloudy days under maximum soybean coverage periods (LAI between 7.2 and 7.5). This corroborates the importance of cloud cover on the control of the long wave net radiation over the ecosystem, regardless of the vegetation cover.

The main issue related to the land use for soybean monoculture in the Amazon region is that there is a constant change in albedo and in the loss of long wave over the cycle, in opposition to that observed in other land use models in the region. As a result of this soybean behavior, it is expected a much bigger impact on the exchange processes between the surface and the atmosphere during a single season of the year, due to the probable reduction on the net radiation.

The mean values found for the long-wave net radiation over the soybean cycle ranged from -2.9 to $-5.2 \mathrm{MJ} \mathrm{m}^{-2}$ day $^{-1}$. The albedo varied between 0.16 and 0.24 , which resulted in a mean net radiation between 9.8 and $12 \mathrm{MJ} \mathrm{m}^{-2}$ day $^{-1}$ depending on the phenological stage. The albedo observed during the same season in other land use models in the Amazon ranged from 0.15 to 0.198 for rice crops (SAKAI et al., 2004), from 0.176 to 0.185 for cassava crops (GIAMBELLUCA et al., 1997 ) and 0.20 to 0.22 for pastures (RANDOW et al., 2004). The mean long wave net radiation commonly found for pasture in the Amazon during the soybean growing season ranged from -2.25 and $4.23 \mathrm{MJ} \mathrm{m}^{-2}$ day $^{-1}$ (RANDOW et al., 2004).

\section{Conclusions}

1. The continuous increase in the reflection and in the emission of long wave by the surface causes a reduction on the available energy throughout the soybean cycle;

2. On cloudy days, the effect of the long wave surface emission becomes less important on the control of 
the long wave net radiation, because of the greater importance of the atmospheric radiation;

3. The soybean presents similar behavior in intercepting the solar radiation during the period of full canopy closure, independent of cloud cover conditions;

4. During incomplete canopy closure, the soybean intercepts more radiation under cloudy days, even with less incident radiation, which demonstrates the importance of the diffuse component of the global radiation in this process.

\section{Acknowledgements}

The authors thank CNPQ for the financial support. The first author thanks CAPES for supporting his postgraduate program.

\section{References}

ALBRIZIO, R.; STEDUTO, P. Resource use efficiency of field-grown sunflower, sorghum, wheat and chickpea I. Radiation use efficiency. Agricultural and Forest Meteorology, v. 130, p. 254-268, 2005.

BLAD, B. L.; BACKER, D. G. Reflected radiation from a soybean crop. Agronomy Journal, v. 64, n. 03, p. 277-280, 1972.

BENINCASA, M. P. Análise de crescimento de plantas (noções básicas). Jaboticabal: Funep, 2003. 41 p.

CAVIGLIA, O. P. et al. Intensifications of agriculture in the south-eastern Pampas I. Capture and efficiency in the use of water and radiation in double-cropped wheat-soybean. Field Crops Research, v. 87, n. 02/03, p. 117-129, 2004.

CENTRO DE PREVISÃO DE TEMPO E ESTUDOS CLIMÁTICOS (CPTEC). Monitoramento dos fenômenos El Niño e La Niña. Disponível em: <http://enos.cptec.inpe.br>. Acesso em: 15 jul. 2007.

COHEN, J. C. P. et al. Influência do desmatamento sobre o ciclo hidrológico na Amazônia. Ciência e Cultura, v. 59, n. 03, p. 36-39, 2007.

COSTA, M. H. et al. Climate change in Amazonia caused by soybean cropland expansion, as compared to caused by pastureland expansion. Geophysical Research Letters, v. 34, 2007.

COSTA, M. H.; YANAGI, S. N. M. Effects of Amazon deforestation on the regional climate - Historical perspective, current and future research. Revista Brasileira de Meteorologia, v. 21, n. 3a, p. 200-211, 2006.

DALMOLIN, R. S. D. et al. Relação entre os constituintes do solo e seu comportamento espectral. Ciência Rural, v. 35, n. 02, p. $481-489,2005$.
DANTAS, T. M.; FONTELES, L. V. Avanço da fronteira agrícola na Amazônia. 2005. disponível em: <http://www. oktiva.net/sispub/anexo/9168>. Acesso em: 15 out. 2006.

DIAS, F. T. C. et al. Adaptabilidade e estabilidade fenotípica para o caráter rendimento de grãos em cultivares de soja para o estado do Ceará. Revista Ciência Agronômica, v. 40, n. 01, p. 129-134, 2009.

EARL, H. J.; DAVIS, R. F. Effect of Drought Stress on Leaf and Whole Canopy Radiation Use Efficiency and Yield of Maize. Agronomy Journal, v. 95, n. 03, p. 688-696, 2003.

FEARNSIDE, P. M. Soybean cultivation as a threat to the environment in Brazil. Environmental Conservation, v. 28, n. 01, p. $23-38,2001$.

FEHR, W. R.; CAVINESS, C. E. Stages of soybean development. Ames: Iowa state university coop. ext. serv, 1977. (Special report, 80).

FONTANA, D. C. et al. Balanço de energia em soja irrigada e não irrigada. Pesquisa Agropecuária Brasileira, v. 26, n. 03, p. 403-410, 1991.

GIAMBELLUCA, T. W. et al. Observations of albedo and radiation balance over postforest land surfaces in the eastern Amazon basin. Journal of Climate, v. 10, p. 919-928, 1997.

RANDOW, C. V. et al. Comparative measurements and seasonal variations in energy and carbon exchange over forest and pasture in South West Amazonia. Theoretical and Applied Climatology, v. 78, n. 01/03, p. 5-26, 2004.

SAKAI, R. K. et al. Land-use change effects on local energy, water, and carbon balances in an Amazonian agricultural Field. Global Change Biology, v.10, p. 895-907, 2004.

SAUER, T. J. et al. Radiation balance and evaporation partitioning in a narrow-row soybean canopy. Agricultural and Forest Meteorology. v. 145, p. 206-214, 2007.

SOUZA, P. J. O. P. et al. Balanço de energia na soja em área de avanço da fronteira agrícola na Amazônia. In: CONGRESSO BRASILEIRO DE AGROMETEOROLOGIA, 15., 2007, Aracaju. Anais... Aracajú: EMBRAPA, 2007. 1 CD-ROM.

SOUZA, P. J. O. P. et al. Impactos no albedo em consequência do avanço da fronteira agrícola na Amazônia. Revista Brasileira de Agrometeorologia, v. 16, n. 01, p. 87-95, 2008.

SOUZA, P. J. O. P. et al. Solar radiation use efficiency by soybean under field conditions in the Amazon region. Pesquisa Agropecuária Brasileira, v. 44, n. 10, p. 12111218, 2009.

SOUZA, P. J. O. P. et al. Albedo da cultura da soja em área de avanço da fronteira agrícola na Amazônia, Revista Brasileira de Engenharia Agrícola e Ambiental, v. 14, n. 01, p. 65-73, 2010.

SOARES-FILHO, B. S. et al. Cenários de desmatamento para Amazônia. Estudos Avançados, v. 19, n. 54, p. 138152, 2005. 